\title{
Chemical and microbiological properties of exudates with sugaring of sea tangle, onion, aloe, maesil, and kale
}

\author{
Mi-Young Choi ${ }^{1}$, Deok-Young Jhon ${ }^{1,2 *}$ \\ ${ }^{1}$ Department of Food and Nutrition, Chonnam National University, Gwangju 61186, Korea \\ ${ }^{2}$ Division of Food and Nutrition, Chonnam National University, Gwangju 61186, Korea

\section{당장법으로 제조한 다시마, 양파, 알로에, 매실 및 케일 삼출액의 화학적 및 미생물학적 특성} \\ 최미영 ${ }^{1} \cdot$ 전덕영 ${ }^{1,2 *}$ \\ ${ }^{1}$ 전남대학교 대학원 식품영양학과, ${ }^{2}$ 전남대학교 식품영양과학부
}

\begin{abstract}
Exudates were prepared using sucrose from the edible parts of sea tangle, aloe, onion, maesil (Prunus mume fruit) and kale. Changes in the amount of sugar and organic acid were investigated during 12-month storage of the exudates in hangari (a traditional Korean jar) and stainless-steel containers. Dominant lactic acid-producing bacteria were isolated and identified. Lactic acid was the major organic acid in the exudates of sea tangle, onion, and aloe, whereas citric acid and acetic acid were the major organic acids in maesil and kale exudates, respectively. In addition, it was confirmed that container type affected the composition of each exudate. Overall, the $\mathrm{pH}$ of these exudates decreased without any significant changes in acidity. As the storage time increased, viable bacterial counts decreased, and the number of acid-producing bacteria also decreased or disappeared. A total of 18 dominant species of lactic acid-producing bacteria were screened and classified into Lactobacillus homohiochii, Lactobacillus plantarum, and Bacillus megaterium based on 16S rRNA gene sequencing. Lactobacillus spp. showed high sugar tolerance and multiplied even at sucrose concentrations of $20-50 \%$. Depending on the strain, these dominant bacteria hydrolyze sucrose to glucose and fructose, with lactic acid as the final product. The dominant type of lactic acid-producing bacteria differed depending on the type of sugaring exudate. Further research on the role of these microorganisms in the food industry, such as preparing exudates using bacterium as a starter material, is required.
\end{abstract}

Keywords : storage properties, exudates, sugaring, sea tangle, plants

서 론

당장법(sugaring)을 적용한 생물재료의 삼출액이 식품 등 여러 분야에 이용되고 있다. 당장법은 당의 삼투압을 이용하 여 생물 조직 내부의 물과 유용성분의 추출 및 미생물 생육을 억제함과 동시에 감미를 부여하는 저장 방법으로 그 과정에
발생하는 액상의 부분을 삼출액이라고 한다. 이것은 당절임 삼출액(Park 등, 2020), 당침출액(Park 등, 2020), 식물발효액 (Han 등, 2012), 발효 추출액(Kim 등, 2011), 청(Kim 등, 2020), 효소식품(Kim 등, 2015; Lee와 Lee, 2001) 등 다양한 이름으로 불리고 있다. 이 당장법에 의한 삼출액은 현재 식품 공전 중 농수산 가공식품류의 효소식품 항목에 해당할 수 있

*Corresponding author. E-mail : dyjhon@gmail.com, Phone : +82-62-530-1335, Fax : +82-62-530-1339

Received 23 July 2021; Revised 24 August 2021; Accepted 07 September 2021.

Copyright (c) The Korean Society of Food Preservation.

This is an Open Access article distributed under the terms of the Creative Commons Attribution Non-Commercial License (http://creativecommons.org/licenses/by-nc/4.0) which permits unrestricted non-commercial use, distribution, and reproduction in any medium, provided the original work is properly cited. 
으나, 당장법과는 관계없이 일정량 이상의 조단백질과 효소 를 함유하는 등 규격 기준에 적합해야 하며, 그 외에도 제품 의 종류에 따라 발효 음료류 등에 포함될 수 있다.

제조하는 방법은 일반적으로 과일이나 채소 등의 생물성 식품 재료에 동량의 당을 혼합하여 실온에서 저장하는 것이 다(Kim 등, 2013). 이 혼합물은 저장 기간이 증가함에 따라 생물조직이 파괴되어 액즙의 형성 등 외관의 변화, 가스의 생 성, 질감이나 냄새, 그리고 색깔 변화 등 여러 면에서 대폭 변하는데 이 과정을 발효로 표현하기도 한다. 따라서 이러한 삼출액의 저장은 단지 식품의 가식 기간을 연장하는 의미의 저장 외에 지속적으로 식품이 제조되는 과정을 포함한다. 한 편, 삼출액의 제조에는 보통 설탕이 사용되나, 올리고당(Kim 등, 2011)이나 꿀(Kim 등, 2020)이 사용되기도 한다.

이러한 당장법에 따른 삼출액은 원료에 따라 그 기능성이 다양하다. 대표적인 것이 다시마, 양파, 알로에, 매실, 케일 등 이다. 이들 원료 중 다시마는 항산화 효과, 항돌연변이, 항균 활성 등의 생물학적 활성을 갖고 있다(Okai 등, 1993; Park 등, 2009; Wang 등, 2006; Yoo 등, 2002). 또한, 양파는 지질 에 대한 항산화 효과(Bracco 등, 1981; Kwak 등, 2000), 항암 작용(Jeong 등, 2009), 항돌연변이 활성(Gwon 등, 1999), 혈 중 콜레스테롤 감소(Kim과 Chun, 1999), 고혈압 및 당뇨병 에 대한 효과(El-Demerdash 등, 2005; Yang 등, 2008) 등 중 요한 생리활성을 가지는 것으로 알려져 있다. 알로에는 항염 증 효과를 나타내며(Cho 등, 2006), 매실은 항산화 활성 (Hwang 등, 2004; Park 등, 2002; Xia 등, 2010), 항균력(Ha 등, 2006; Ko와 Yang, 2009), 항암 효과(Bae 등, 2000; Chuda 등, 1999) 등이 있는 것으로 보고되었다. 케일은 발암 억제 효과(Cheigh 등, 1998; Kim 등, 1999; Park, 등, 1992)와 항 암성(Hertog 등, 1992)이 알려져 있다.

그러나 시판 당장법에 의한 이들 삼출액에 대하여는 명확 한 정의와 규격, 제조 기술의 과학화, 고품질 상품화, 식품의 안전성 확보 등의 면에서 충족되지 못한 부분이 있어 고시형 건강기능 식품 유형에서 제외되었다(Han 등, 2012). 따라서 본 연구에서는 당장법에 의한 삼출액의 과학적인 이해를 위 해 다시마, 양파, 알로에, 매실 및 케일을 원료로 하여 설탕을 이용한 당장법에 의한 삼출액을 만들고, 1 년 동안 저장하는 동안 주요 화학적 성분의 변화를 확인하고, 우점종 젖산 생성 세균을 분리 및 동정하고, 이에 대한 미생물학적 특성을 조사 하였다. 또한, 전통적인 항아리 저장 방법을 대신하여 스텐리 스강 용기가 사용될 수 있는지도 알고자 하였다.

\section{재료 및 방법}

\section{당을 이용한 삼출액 제조}

삼출액의 제조에는 (주)건강을지키는사람들(나주, 전남)의 생
산 설비가 이용되었다. 다시마, 양파, 알로에, 매실, 케일을 시 중(광주광역시 각화동 농산물 도매시장)에서 구입하여 가식 부위를 실험재료로 사용하였다. 각 원료를 깨끗이 씻고, 다시 마와 알로에 그리고 케일은 사전 절단작업을 거쳤다. 그리고 모든 원료를 각각 롤러를 이용하여 약 $2 \mathrm{~mm}$ 이하로 잘게 분 쇄하고, 설탕을 총량의 $50 \%(\mathrm{w} / \mathrm{w})$ 가 되게 첨가하여 각각 유 약을 바르지 않은 항아리 $(180 \mathrm{~L})$ 와 스텐리스강 재질의 용기 $(200 \mathrm{~L})$ 에 넣어 당장하였다. 저장 온도는 $20-25^{\circ} \mathrm{C}$, 습도는 $30 \pm 1 \%$ 를 유지했다. 저장 기간 동안 주 2 회 교반하였다. 당장 개시 후 $1,2,3,6$ 개월 그리고 12 개월째에 $75 \mathrm{~mL}$ 의 각 시료 를 무균적으로 채취하여 즉시 실험하였다.

\section{$\mathrm{pH}$, 산도, 당 및 유기산 분석}

$\mathrm{pH}$ 는 시료액 $20 \mathrm{~mL}$ 에 대하여 $\mathrm{pH}$ meter(Model 520, Orion Research Inc., Boston, MA, USA)를 이용하여 측정하 였다. 총산도는 각 시료액 $10 \mathrm{~g}$ 에 증류수 $100 \mathrm{~mL}$ 를 가하여 혼합한 후 $0.1 \mathrm{~N}-\mathrm{NaOH}$ 용액으로 $\mathrm{pH} 8.3$ 이 될 때까지 적정하 여 소비된 $\mathrm{NaOH}$ 용액의 양 $(\mathrm{mL})$ 을 젖산 함량(\%)으로 나타냈 다. 당(설탕, 포도당, 과당)과 유기산(구연산, 주석산, 호박산, 젖 산, 초산, 프로피온산)은 HPLC(Shimadzu LC-20AD, Shimadzu Co., Kyoto, Japan)를 이용하여 분석하였다. 즉, 시료액은 Sep-pak ${ }^{\circledR}$ plus C18 cartridges(Waters, Milford, MA, USA)로 정제하여 $20 \mu \mathrm{L}$ 를 $30^{\circ} \mathrm{C}$ 로 유지된 컬럼(Aminex $\mathrm{HPX}-87 \mathrm{H}$, Bio.Rad laboratories)에 주입하였다. 이동상으로는 $6.5 \mathrm{mM}$ $\mathrm{H}_{2} \mathrm{SO}_{4}$ 를 $0.5 \mathrm{~mL} / \mathrm{min}$ 유속으로 사용하였으며, 검출기는 당의 분석에 RI 검출기(Shimadzu RID-10A), 유기산의 분석에는 UV 검출기(Shimadzu SPD-20A, UV $210 \mathrm{~nm}$ )를 사용하였다.

\section{세균수의 측정 및 젖산 생성 세균 분리}

일반세균수의 측정은 식품공전에 수록된 PCA 배지를 사 용한 표준평판법으로 수행하였다. 젖산생성 세균은 $20 \%$ 포도 당과 $1 \%$ 탄산칼슘을 첨가한 MRS 한천(Difco Lab., Sparks, $\mathrm{MD}, \mathrm{USA}$ ) 배지를 사용하였다. 먼저 시료를 단계적으로 희 석하여 평판 표면에 도말법으로 접종한 후 $30^{\circ} \mathrm{C}$ 에서 $7-10$ 일 간 배양하였다. 그리고 배지 중에 투명 환을 형성하는 모든 집락을 젖산생성 세균으로 선택하였으며, 순수분리를 위하여 3 회 계대 배양하였다. 젖산을 생성하는 우점종 세균은 희석 배수를 높인 평판으로부터 선발하였다.

\section{균주 동정}

탄수화물 대사에 의한 예비동정은 API $50 \mathrm{CH}$ 키트 (BioMerieux, Marcy, l'Etoile, France)를 이용하였으며, 16S rRNA 유전자 염기서열 분석으로 최종적으로 확인하였다. $16 \mathrm{~S}$ rRNA 유전자의 증폭(Baker 등, 2003)은 콜로니 PCR을 
사용하였다. 단일 colony로부터 1 toothpick 채취하여 PCRpremix(iNtRON Biotechnology, Korea)와 혼합한 후, bacteria 에 특이적인 primer(8F 5'-AGAGTTTGATCCTGGCTCAG-3'; 1492R 5'-TACGGYTACCTTGTTACGACTT-3')를 사용하여 $94^{\circ} \mathrm{C}$ 에서 30 초간 변성, $55^{\circ} \mathrm{C}$ 에서 30 초간 결합, $72^{\circ} \mathrm{C}$ 에서 50 초의 신장 조건으로 $22 \mathrm{cycle}$ 을 행한 후 최종적으로 $72^{\circ} \mathrm{C}$ 에 서 10 분간 $\mathrm{DNA}$ 를 증폭시켰다. 증폭된 PCR 산물 크기를 $1 \%$ agarose gel에서 확인한 후, (주)Solgent에서 16S rRNA 유전자 염기서열을 분석하였다.

각 미생물의 $16 \mathrm{~S}$ rRNA 염기서열에 대하여 GenBank data base(NCBI database)를 통해 기존에 보고된 미생물의 유전자 염기서열과 상동성을 비교하였다. 그리고 각 염기서열을 Bio Edit Sequence Alignment Editor program(version 7.0.5; North Carolina State University, Raleigh, NC, www.mbio.ncsu.edu/ BioEdit/bioedithtml)의 ClustalW Multiple alignment로 Multiple Sequence Alignment한 후, MEGA 4.0을 사용하여 phylogenetic tree를 작성하였으며, 해당 분석은 neighbor-joining 알고리즘 을 사용하였다(Tamura 등, 2007).

\section{분리 균주의 생육 및 발효}

농도별 $(0 \%, 10 \%, 20 \%, 30 \%, 40 \%$ 그리고 $50 \%, \mathrm{w} / \mathrm{w})$ 로 설탕을 첨가한 MRS 액체 배지 $10 \mathrm{~mL}$ 에 흡광도 값이 0.4 가 될 때까지 배양된 세균 배양액 $10 \mu \mathrm{L}$ 를 각각 접종하여 $30^{\circ} \mathrm{C}$ 에서 배양하면서 UV-Vis spectrophotometer(S-1100, Scinco, Seoul, Korea)를 이용하여 $660 \mathrm{~nm}$ 에서 24시간 간격으로 4일 동안 측정하였다(Saitou와 Nei, 1987). 그리고 각 미생물이 4
일 동안 시료 중에 생육하면서 생산 또는 소비한 당과 유기산 의 함량을 HPLC를 이용하여 분석하였다.

\section{통계처리}

통계분석은 SPSS for Windows(version 17.0, SPSS Inc., Chicago, IL, USA)를 이용하여 분산분석(ANOVA)과 Duncan 의 다중검정법(Duncan's multiple range test)으로 시료 간의 유의차를 검증하였다 $(\mathrm{p}<0.05)$.

\section{결과 및 고찰}

\section{$\mathrm{pH}$, 산도, 당 및 유기산 함량의 변화}

식품 재료와 당을 동량으로 당장하면서 기간별 $\mathrm{pH}$ 는 전체 적으로 점점 낮아졌으며, 이 경향은 저장 용기의 종류와는 관 계가 없었다(Fig. 1). 매실의 경우, 당장 6개월째에 다른 4종 류의 삼출액보다 현저히 낮은 값(2.90-2.99)을 나타내었다. 당장 개시 후 1 개월 만에 다시마의 경우(pH 4.55-4.59)를 제 외하고, 모두 $\mathrm{pH} 4$ 이하가 되었다. 이들 원재료의 $\mathrm{pH}$ 는 각각 다시마 5.78, 양파 5.84-6.18, 알로에 5.24, 매실 2.73, 케일 5.24로 보고된 바 있다(Bae와 Kim, 2010; Kim 등, 2018; Muñoz 등, 2015; Noisopa 등, 2010; Oancea와 Draghici, 2018). 그러므로, 본 연구에서 설정한 시료 최초 채취일인 당 장 1 개월째에는 이미 삼출 과정이 상당 부분 진행되었을 것 으로 판단되었다. 모든 삼출액의 $\mathrm{pH}$ 는 당장 6 개월 이후에는 안정적으로 낮은 값을 나타냈다. 다시마와 양파의 경우만 서 로 다른 통에 저장할 경우, 각각 스텐리스강 용기와 항아리에

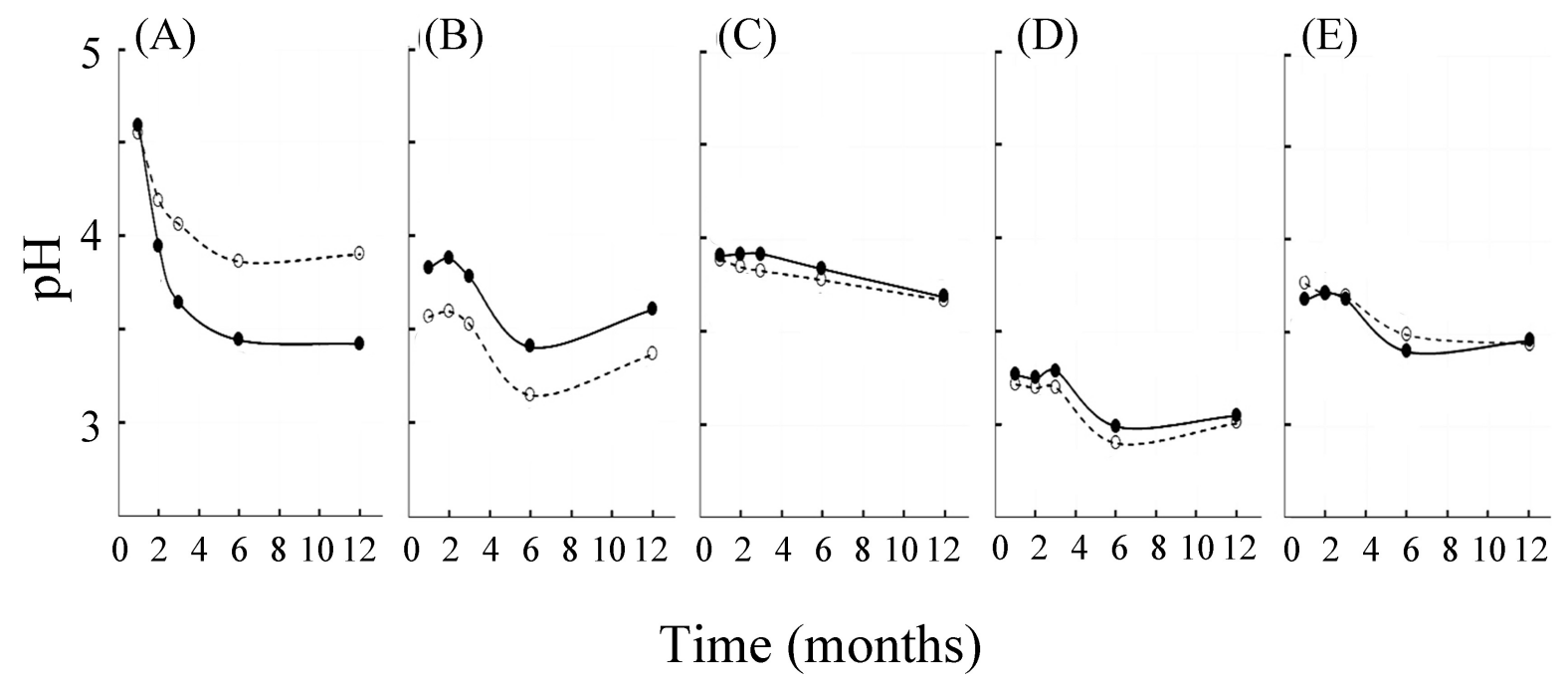

Fig. 1. pH of exudates of sea tangle, onion, aloe, maesil, and kale stored in a Korean jar and stainless steel container. (A), sea tangle; (B), onion; (C), aloe; (D), maesil, (E), kale. Dotted line with open circle denotes the traditional Korean jar, hangari, and solid line with filled circle denotes stainless steel container. Storage temperature was $20-25^{\circ} \mathrm{C}$. Data points are mean values of independent measurements in triplicate. 
서 $\mathrm{pH}$ 가 더 낮았다. 따라서 추후 품질 검사를 바탕으로 하여 시료에 따라 더 적절한 저장 용기의 선택이 가능할 것이다. 이러한 $\mathrm{pH}$ 의 감소는 시료에 따라 저장 초기에 내삼투압성을 갖고 있으며, 산을 생성하는 미생물이 존재할 가능성이 있음 을 시사한다(Son 등, 2005). 그런데 매실 삼출액은 당장 초기 부터 $\mathrm{pH}$ 3.5에서 생육할 수 있는 젖산균마저 증식하기 어려 운 정도의 낮은 $\mathrm{pH}$ 를 보였다(Song과 Jung, 2006). 일반적으 로 강산보다는 해리도가 낮은 유기산이 미생물에게는 더 치 명적이라고 알려져 있다(Warnecke와 Gill, 2005). 따라서 저 장 12 개월째에 접어든 5 종의 삼출액은 $\mathrm{pH} 3.5$ 정도로서 그 저장성이 우수할 것으로 생각한다.

한편, 당장 기간별 총산도의 변화는 1 개월 저장한 삼출액들 의 경우 산도 $(\%)$ 가 다시마(항아리: $0.36 \pm 0.15$, 스텐리스강 용 기: $0.48 \pm 0.27)$, 양파 $(0.76 \pm 0.28,0.73 \pm 0.08)$, 알로에 $(0.83 \pm 0.23$, $0.75 \pm 0.23)$, 매실 $(2.77 \pm 0.54,3.29 \pm 0.74)$, 케일(1.02 \pm 1.05 , $1.49 \pm 0.31$ )로서 $\mathrm{pH}$ 의 경우와는 달리 12 개월까지 등락하는 양상이었으나 유의미한 차이는 아니었다(data not shown).

당장 기간에 따라 삼출액 중에는 첨가된 이당류인 설탕의 함량이 감소하는 대신 단당류인 포도당과 과당의 함량은 증 가하였다(Fig. 2). 이러한 설탕의 분해 속도는 삼출액 제조 원 료에 따라 다름을 알 수 있었다. 저장 2 개월째에 다시마가 약 $30 \%$ 의 설탕 농도를 보인 반면, 알로에와 양파는 거의 남아 있지 않은 정도를 보여 빠르게 분해되었음을 알 수 있다. 설 탕은 산이나 효소에 의해 그 구성 당인 포도당과 과당으로 가수분해된다. $\mathrm{pH}$ 감소 폭이 작은 다시마의 경우만 포도당
농도 증가속도가 현저하게 작은 것으로 보아, 설탕의 분해에 의한 포도당과 과당의 생산이 삼출액 중에서 산의 영향을 받 음을 알 수 있다. 대두와 유산발효 대두의 유리당을 분석한 연구에서는 발효 후에 전체적인 유리당의 총량이 현저히 감 소하였는데, 이는 발효과정 중 미생물에 의해 당류가 영양원 으로 이용되었기 때문으로 보고하였다(Song과 Jung, 2006). 본 실험에서는 설탕, 포도당 그리고 과당의 세 가지 당을 합 한 총 당의 함량이 당장 기간의 증가에 따라 크게 변화하지는 않았다. 이는 당류가 미생물에 의해 다량 이용되지 않았음을 시사하며, 설탕의 분해는 미생물 효소 작용보다는 유기산에 의한 산 가수분해임을 보여준다. 그러나 저장 1 개월째에 채 취한 시료의 $\mathrm{pH}$ 가 매우 낮은 것으로 보았을 때 1 개월 전까지 는 미생물이 당류를 분해하여 산을 생성했을 수 있다(Son 등, 2005). 또한, 저장 용기에 따른 변화로는 특히 다시마의 경우, 저장 초기에는 스텐리스강 용기의 경우보다 항아리 용기 중 의 설탕 분해가 적었으나, 3 개월 이후에는 더 많은 양이 분해 되어 용기에 따른 영향이 관찰되었다(Fig. 2). 즉, 이러한 차 이가 나는 것은 항아리의 미세기공을 통한 공기의 출입과 관 련이 있다고 사료된다(Han 등, 2013).

당장 기간에 따른 유기산의 종류 및 함량은 삼출액 제조 원료에 따라 다르게 나타났다(Fig. 3). 다시마의 경우, 구연산, 주석산, 호박산, 젖산, 초산 그리고 프로피온산이 모두 검출 되었고, 저장 기간에 따라 감소 또는 증가하는 유기산의 종류 가 다름을 확인하였다. 저장 1 개월 이후 삼출액 중의 유기산 함량은 매실, 알로에, 양파의 경우 $100 \mathrm{~g}$ 당 0.8-1 g 정도였
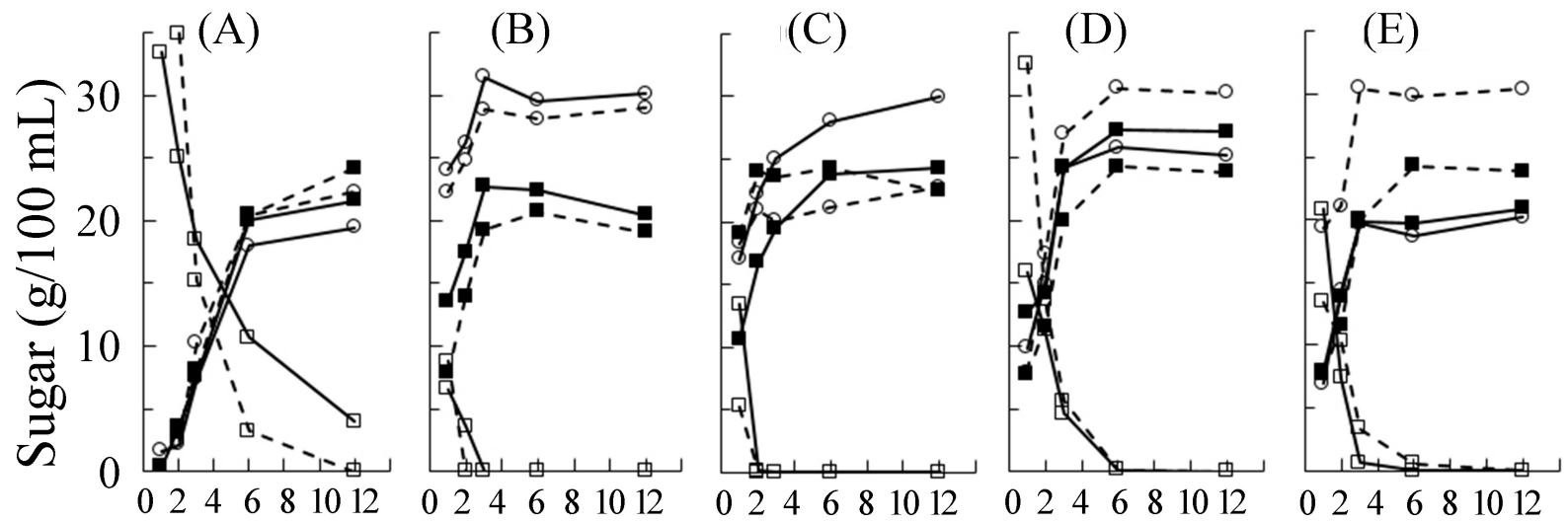

\section{Time (months)}

Fig. 2. Changes in sucrose, glucose, and fructose amounts in stored exudates of sea tangle, onion, aloe, maesil, and kale prepared using sugar.

(A), sea tangle; (B), onion; (C), aloe; (D), maesil; (E), kale.

Dotted line denotes the traditional Korean jar, hangari, and solid line with denotes a stainless steel container. Open square, filled square, and open circle represent sucrose, fructose, and glucose, respectively. Storage temperature was $20-25^{\circ} \mathrm{C}$. Data points are mean values of independent measurements in trplicate. 


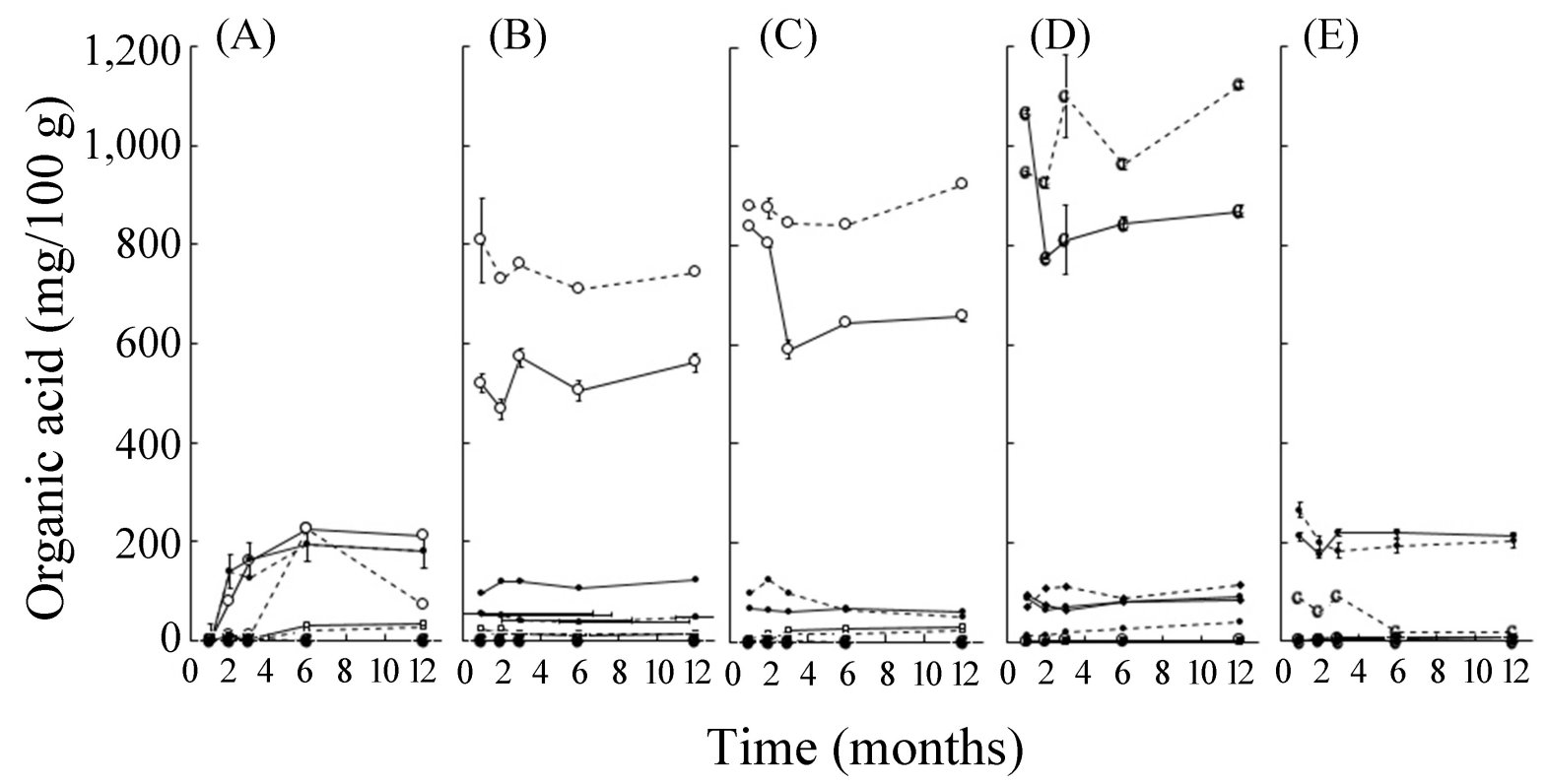

Fig. 3. Organic acid content in sugar exudates of sea tangle, onion, aloe, maesil, and kale during storage.

(A), sea tangle; (B), onion; (C), aloe; (D), maesil; (E), kale.

Dotted line denotes the traditional Korean jar, hangari, and solid line denotes a stainless steel container. Open circle, lactic acid; c, citric acid; open triangle, acetic acid; filled square, tartaric acid; filled circle, succinic acid; filled diamond, propionic acid.

Data points are mean \pm SE $(n=3)$.

다. 이와는 달리 다시마와 케일은 $0.2 \mathrm{~g}$ 의 낮은 값을 보였다. 한편, 다시마, 양파, 알로에는 유기산 중 젖산이 가장 많았으 며 이 중에서 양파와 알로에는 항아리를 사용한 경우가 더 많았다(Han 등, 2013). 한편, 매실 삼출액 중에는 구연산이 다 량 들어 있었으며, 케일은 전체적인 유기산의 함량은 적으나, 그중에서 초산함량이 가장 많았다. 매실 삼출액 중의 높은 구 연산의 함량은 원재료에(Shin, 1995) 기인하나, 케일 중의 초 산은 원재료 중에는 함유되지 않아 삼출액 저장 중 생산된다 고 할 수 있다(Ayaz 등, 2006).

\section{삼출액 중의 일반세균수와 우점종 젖산 생성 세균의 분리}

삼출액 중의 일반세균수는 저장 기간이 늘어남에 따라 용 기와는 무관하게 감소하였다(Fig. 4). 저장 1개월 후부터는 다 시마의 $10^{7}-10^{8} \mathrm{CFU} / \mathrm{mL}$ 를 제외하고, 다른 시료들은 $10^{3}-10^{6}$ $\mathrm{CFU} / \mathrm{mL}$ 의 범위를 보였다. 모든 시료가 저장 3-6개월까지는 일반세균수가 감소하였고, 이후 그 수준을 유지하였다. 특히 매실의 경우에는 저장 6 개월 이후에는 세균이 검출되지 않았 다. 이는 매실 중의 구연산이 갖는 세균 사멸 효과 때문일 수 도 있다. 따라서 삼출액의 저장 중에는 저장 1 개월 이후에는 미생물이 생육하는 양상을 보이지 않았으므로 이 기간의 변 화는 일반적인 발효과정이라고 할 수 없으며, 원재료 조직 중 의 효소와 미생물의 용균에 따른 균체 효소가 작용한 결과일 수도 있다(Rice와 Bayles, 2008).
$20 \%$ 포도당과 $1 \%$ 탄산칼슘을 첨가한 MRS 한천배지를 이 용하여 삼출액 중의 젖산생성 세균을 분리하였을 때 5 종의 삼 출액은 발효 1 개월째에는 젖산생성 세균 수가 $2 \times 10^{2}-2 \times 10^{5}$ $\mathrm{CFU} / \mathrm{mL}$ 이하로 나타났다(Fig. 5). 그리고 저장 기간이 지남 에 따라 그 수가 점점 줄어들어 12 개월째에는 $2 \times 10^{1}-1 \times 10^{2}$ $\mathrm{CFU} / \mathrm{mL}$ 이하가 되었다. 대상 우점종 미생물은 다시마 삼출 액에서 발효 2 개월째에 2 종, 알로에 삼출액에서 발효 1 개월 째에 3종, 양파 삼출액 저장액에서는 발효 12개월째에 2종, 그리고 케일 삼출액에서는 발효 3 개월과 6개월째에 11종이 분리되었으며, 매실 삼출액 저장액에서는 산을 생산하는 세 균을 검출할 수 없었다.

\section{분리 균주의 동정}

매실을 제외한 다시마, 양파, 알로에 그리고 케일 삼출액 저장액에서 산 생성균으로서 선발된 총 18 균주의 염기서열 을 BioEdit Sequence Alignment Editor program의 ClustalW Multiple alignment를 이용하여 비교한 결과, 크게는 3개, 세 부적으로는 9개로 균주를 구분할 수 있었다(Table 1). 크게 나누었을 때는 SS2-22와 SS2-29, AS1-10, AS1-15, AS1-21 과 양파와 케일에서 분리한 나머지 미생물로 나누어졌다. 일 단 SS2-22는 나머지 17 균주와 다른 염기서열을 가지고 있었 다. SS2-29와 AS1-10, 15, 21은 염기서열 하나만 달랐고, 양 파와 케일에서 분리된 13 개의 미생물은 각각의 $16 \mathrm{~S} \mathrm{rRNA}$ 염. 

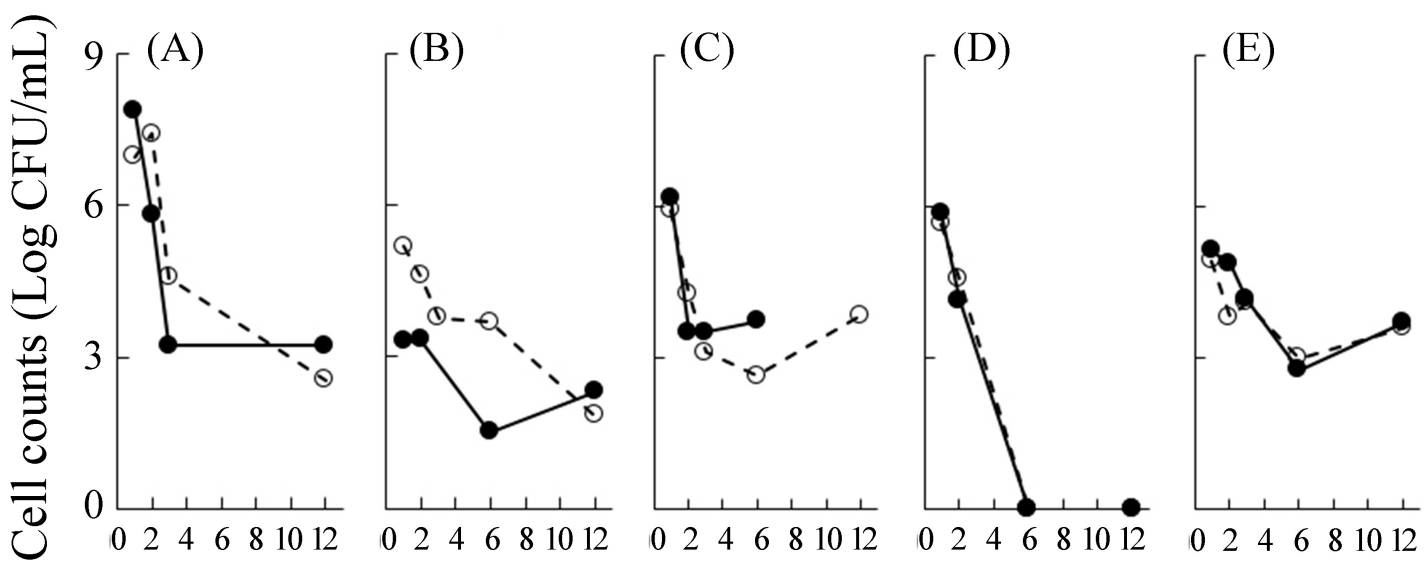

Time (months)

Fig. 4. Viable bacterial counts of stored exudates of sea tangle, onion, aloe, maesil, and kale prepared using sugar.

(A), sea tangle; (B), onion; (C), aloe; (D), maesil; (E), kale.

Dotted line with open circle denotes the traditional Korean jar, hangari, and solid line with filled circle denotes a stainless steel container. Storage temperature was $20-25^{\circ} \mathrm{C}$. Data points are mean \pm SE $(n=3)$.
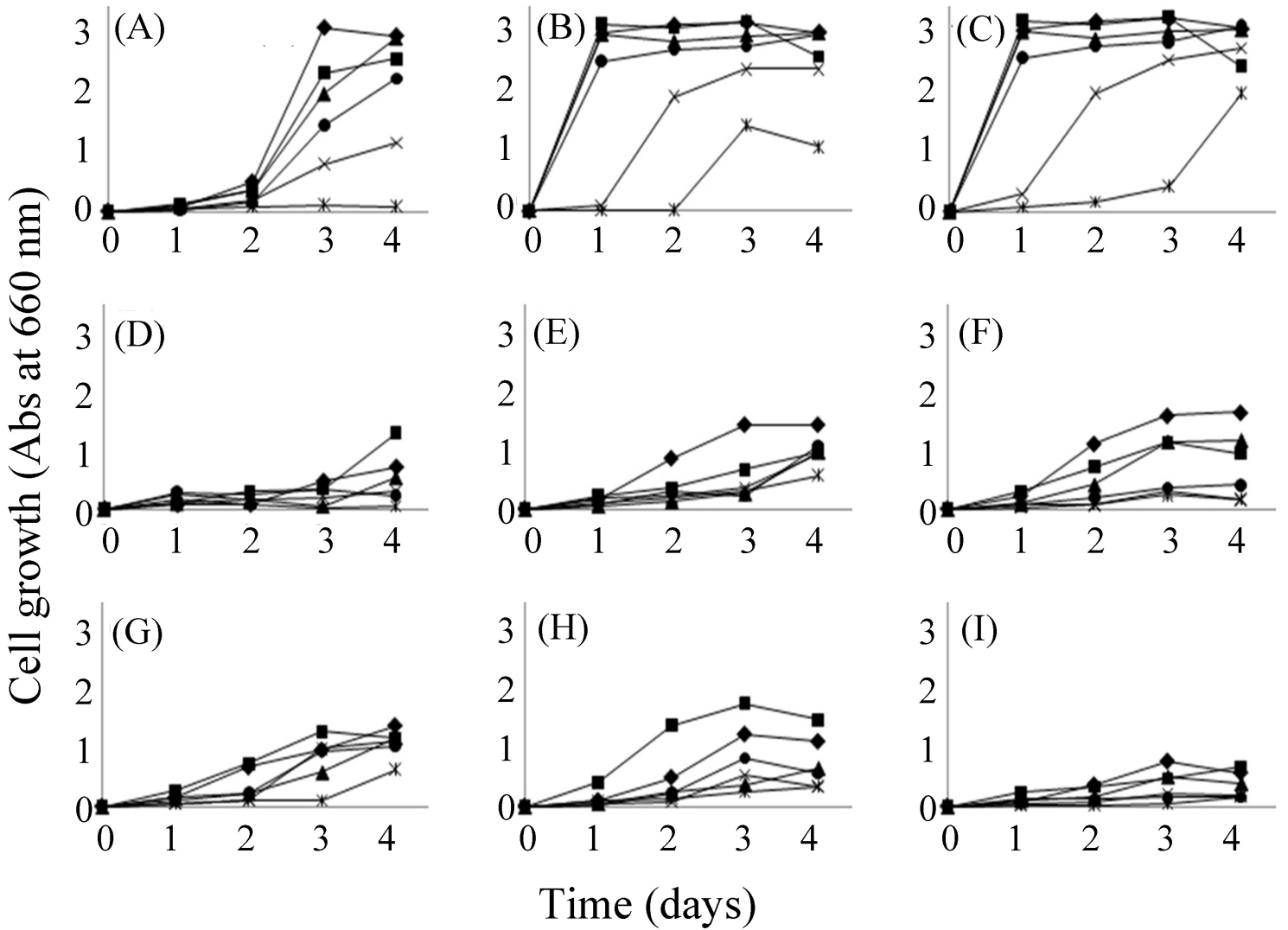

Fig. 5. Growth curves of isolated bacteria in MRS medium with added sucrose.

(A)-(I) indicate isolated bacterial strains SS2-22, SS2-29, AS1-10, KJ3-19, KS3-2, KJ6-1, KJ6-2, KJ6-12, and KS6-2, respectively. MRS broth and MRS broth with added sucrose $(\bullet, 10 \% ; \boldsymbol{\Lambda}, 20 \%$;

$30 \% ; \times, 40 \% ; *, 50 \%)$. Data points are mean \pm SE $(n=3)$ 
Table 1. Carbohydrate fermentation characteristics of acid-producing bacteria from exudates using sucrose by the API 50 CH kit

\begin{tabular}{|c|c|c|c|c|c|c|c|c|c|c|c|c|c|c|c|c|c|}
\hline Carbohydrates | Strains & $\begin{array}{c}\text { SS2- } \\
22\end{array}$ & $\begin{array}{c}\text { SS2- } \\
29\end{array}$ & $\begin{array}{c}\text { AS1-10, } \\
1-15 \\
1-21\end{array}$ & $\begin{array}{c}\text { KJ6- } \\
3\end{array}$ & $\begin{array}{c}\mathrm{KJ} 3- \\
3\end{array}$ & $\begin{array}{c}\text { KJ3- } \\
19\end{array}$ & $\begin{array}{c}\text { KS3- } \\
2\end{array}$ & $\begin{array}{c}\text { KJ6- } \\
17\end{array}$ & $\begin{array}{c}\text { OJ12- } \\
2\end{array}$ & $\begin{array}{c}\text { KJ6- } \\
2\end{array}$ & $\begin{array}{c}\text { OS12- } \\
1\end{array}$ & $\begin{array}{c}\text { KJ6- } \\
6\end{array}$ & $\begin{array}{l}\text { KJ6-1, } \\
\text { KS6-1 }\end{array}$ & $\begin{array}{c}\text { KJ6- } \\
12\end{array}$ & $\begin{array}{c}\text { KS6- } \\
2\end{array}$ & $\begin{array}{c}B . \\
\text { mega- } \\
\text { terium }\end{array}$ & $\begin{array}{c}L . \\
\text { planta- } \\
\text { rum }^{1)}\end{array}$ \\
\hline D-Glucose, D-fructose & + & + & + & + & + & + & + & + & + & + & + & + & + & + & + & + & + \\
\hline $\begin{array}{l}N \text {-Acetyl glucosamine, } \\
\text { L-Arabinose, Arbutin, } \\
\text { D-Cellobiose, } \\
\text { Esculin ferric citrate, } \\
\text { Gentiobiose, D-Maltose, } \\
\text { D-Mannitol, D-Melibiose, } \\
\text { D-Ribose, D-Saccharose } \\
\text { (sucrose), Salicin, } \\
\text { D-Trehalose }\end{array}$ & - & + & + & + & + & + & + & + & + & + & + & + & + & + & + & + & + \\
\hline Amidon (starch) & - & - & - & + & + & + & + & + & + & + & + & + & + & + & + & + & - \\
\hline Amygdalin & - & + & + & + & + & + & + & - & + & + & - & + & + & + & + & + & + \\
\hline D-Arabitol & - & + & - & - & - & - & - & - & - & - & + & - & - & - & - & - & - \\
\hline D-Galactose & - & + & + & + & - & + & + & + & - & + & + & + & + & + & + & + & + \\
\hline Glycerol & - & - & - & - & + & + & + & + & + & + & + & + & + & + & + & + & - \\
\hline Glycogen & - & - & - & + & + & + & + & + & + & + & + & + & + & + & + & + & - \\
\hline Inositol & - & - & - & - & - & - & - & - & - & - & - & + & + & + & + & + & - \\
\hline Inulin & - & + & + & - & - & - & - & - & - & - & - & - & + & + & + & + & - \\
\hline D-Lactose (bovine origin) & - & + & + & + & + & - & - & + & - & + & + & + & - & + & + & + & + \\
\hline D-Mannose & - & + & + & - & - & - & - & - & - & - & - & - & - & + & - & - & + \\
\hline D-Melezitose & - & - & - & - & - & + & - & - & + & + & + & + & - & - & - & - & + \\
\hline Methyl- $\alpha$-D-mannopyranoside & - & - & - & - & - & - & - & - & - & - & - & - & - & - & - & - & + \\
\hline Potassium gluconate & - & + & + & - & + & - & - & - & - & - & + & - & - & - & - & - & + \\
\hline D-Raffinose & - & - & - & + & + & + & + & + & + & + & + & + & + & + & + & + & + \\
\hline D-Sorbitol & - & + & + & - & - & + & - & - & - & - & + & + & - & - & - & - & + \\
\hline D-Turanose & - & + & + & - & + & + & + & - & + & + & + & + & + & - & + & + & + \\
\hline D-Xylose & - & - & - & - & - & - & + & + & + & + & + & + & + & + & + & + & - \\
\hline
\end{tabular}

D-Adonitol, D-Arabinose,

L-Arabitol, Dulcitol,

Erythritol, D-Fucose,

L-Fucose, D-Lyxose,

Methyl- $\alpha$-D-glucopyranoside,

Methyl- $\beta$-D-xylopyranoside,

Potassium 2-ketogluconate,

Potassium 5-ketogluconate,

L-Rhamnose, L-Sorbose,

D-Tagatose, Xylitol,

L-Xylose

+: Positive, -: Negative.

${ }^{1)}$ The source of references is API Manual.

기서열이 작게는 4개, 많게는 9개가 달랐다(data not shown). 이를 동정한 결과, Lactobacillus homohiochii. Lactobacillus plantarum 그리고 Bacillus megaterium으로 나타났으며, 99-
$100 \%$ 의 유사성을 나타내었다. SS2-22 균주는 다시마 시료에 서 분리되었는데, L. homohiochii $\mathrm{LMG} 9478^{\mathrm{T}}$ 와 가장 높은 염기서열 유사성(\% identity 99)을 나타내었다. 또, 다시마에 
서 분리된 SS2-29는 L. plantarum으로 확인되었다 $\%$ identity 100). 알로에 시료 중의 AS1-10, AS1-15, AS1-21은 동정 결 과, 모두 L. plantarum인 것으로 나타났다. 양파 삼출액과 케 일에서 분리된 13 개 균주는 B. megaterium에 속하였는데, 4 개의 균주(KJ3-19, KJ6-1, KJ6-2, KS6-2)가 \% identity 99이 었으며, 그 외는 모두 $100 \%$ 를 나타냈다. B. megaterium은 젖 산을 생성할 수는 있지만, 젖산세균으로 분류되지 않고 있다. 또한, 이들이 발견된 케일 삼출액 중의 산 조성도 젖산의 함 량이 아주 낮아, 비록 해당 삼출액 중에서 산 생성균으로 발 견되었지만 그 역할은 미미한 것으로 보인다.

따라서 산을 생성하는 우점종 세균은 삼출액 원료에 따라 다 른 것을 알 수 있다. 즉, 다시마 삼출액 중에는 L. homohiochii 와 L. plantarum, 알로에에는 L. plantarum, 양파와 케일의 경 우에는 B. megaterium이 우세하였다.

\section{분리된 세균의 미생물의 탄수화물 이용 특성}

5 종의 삼출액으로부터 당장 기간에 따라 선발된 우점종 균주 18 종을 $30^{\circ} \mathrm{C}$ 에서 배양 및 순수 분리한 후 $\mathrm{API}$ system으로 탄소 원 이용성을 확인하였다. API $50 \mathrm{CHL}$ 배지 및 API $50 \mathrm{CHB}$ 배 지로 49종의 탄수화물 대사를 조사한 결과는 Table 1과 같다. L. homohiochii로 확인된 SS2-22는 49종의 탄소원 중에 D-포 도당과 D-과당만을 이용할 수 있어 다른 분리 미생물과는 확 연한 차이가 있었다. 따라서 이 세균은 다시마 삼출액 중에서 설탕이 화학적인 방법으로 분해되어 생산되었거나, 원료 고 유의 포도당이나 과당만을 이용하여 생육할 수밖에 없다. $L$. plantarum으로 확인된 SS2-29, AS1-10, 15, 21은 49종의 탄 소원 중 공통적으로 L-arabinose를 비롯한 23종의 탄소원 이 용성을 가지고 있었으며, SS2-29만 D-arabitol에 양성반응을 나 타냈다. 특히 식물 조직을 구성하는 셀룰로스, 헤미셀룰로스, 펙틴, 키틴질 등 다당류의 분해산물인 D-ribose, D-cellobiose, D-galactose, L-arabinose, $N$-acetylglucosamine, gluconate 등 을 이용하는 능력을 갖고 있어 삼출액 중에서 활발하게 생육 및 발효한 것으로 보인다. B. megaterium으로 확인된 나머지 13 균주는 21-27종의 탄소원을 이용할 수 있으며, 글리세롤, D-xylose 등 11가지 탄소원에 대해서는 그 이용 능력이 균주 마다 조금씩 차이가 있었다.

\section{분리 균주의 생육 및 발효 특성}

분리 동정된 균주의 발효 특성을 검토하기 위하여 이들의 $16 \mathrm{~S}$ rRNA 염기서열의 phylogenetic tree를 바탕으로 하여 9 종으로 압축하였다(data not shown). 이 선발된 균주를 설탕 농도를 달리한 배지에 각 균주를 4 일간 생육시킨 후에 그 생 육 정도와 당의 함량, 그리고 유기산 함량의 변화를 조사하였 다(Fig. 5). 대조구로 사용한 MRS 액체 배지는 발효 전 상태
이지만, 소량의 포도당이 함유되어 있었다. 또, 유기산으로서 소량의 구연산, 호박산, 젖산 그리고 초산이 함유된 것으로 조 사되었다(data not shown). 케일에서 분리한 B. megaterium의 경우(6종), Lactobacillus sp.보다 낮은 생육도를 보였다. 각 균주는 $50 \%$ 설탕 함유 배지를 제외한 모든 배지에서 생육하 였다(Fig. 5). 특히 분리된 L. plantarum이 잘 생육하여 이 균 주가 내삼투압성이 큼을 알 수 있었다(Fig. 5(B), 5(C)), L. homohiochii SS2-22는 설탕 함량이 50\%인 경우 4일 동안에 는 전혀 생육하지 않았다. 이는 이 미생물이 설탕을 이용하지 못하는 위 실험결과와 일치한다. B. megaterium 균주들은 생 육 양상이 서로 유사하였다. 그러나 Lactobacillus 속의 종류 들보다는 생육 정도가 낮지만 4일 동안 모든 당 농도에서 꾸 준한 생육 양상을 나타냈다. 그리고 설탕의 함량은 첨가한 농 도별로 다르게 나타났다(Fig. 6). 당 농도 중 20-40\%일 경우 설탕의 분해와 포도당과 과당 증가가 큰 것을 알 수 있다. $B$. megaterium 균주들에 의한 발효의 경우 포도당과 과당의 생산 능력이 Lactobacillus의 경우보다 컸다. 이들 균주에 의한 주된 유기산 생성은 젖산과 초산의 생성에 있어서 Lactobacillus가 Bacillus보다 10배 정도로 많음을 알 수 있다(Fig. 7). 그러나 L. homohiochii SS2-22는 40\% 이상의 설탕 조건에서는 젖산 이 거의 생산되지 않았다. 이는 Fig. 2에서 확인된 것처럼 $40-50 \%$ 의 설탕 농도에서 잘 생육하지 못하기 때문으로 보인 다. 모든 당 농도 조건에서 젖산을 잘 생산하는 균주는 $L$. plantarum이었다. 초산의 경우 모든 균주에서 $100 \mathrm{~mL}$ 당 0.3 $\mathrm{g}$ 정도로 일정하게 생산됨을 알 수 있었다.

다시마와 양파, 그리고 알로에, 매실 및 케일을 재료로 하 여 설탕을 사용한 당 삼출액을 각각 만들고, 이것을 1-12개월 간 저장 후 당과 유기산을 분석하였다. 그리고, 산을 생성하 는 세균을 분리하여 동정하였다. 저장 기간 동안 모든 삼출액 의 $\mathrm{pH}$ 는 낮아졌다. 설탕은 분해 및 감소되었지만, 포도당과 과당 함량이 늘어나서 전체적으로 당의 함량에는 큰 변화가 없었다. 주요 유기산은 젖산, 구연산, 초산이었으며, 그 양은 삼출액에 따라 달랐다. 또한, 항아리와 스테인리스강 용기를 비교할 때 시료의 종류에 따라 산의 종류별 생성도가 다름이 확인되었다. 이는 삼출액 최종제품의 기호도 향상 조건에 용 기의 선택이 고려사항이 될 수 있음을 의미한다. 일반 세균과 젖산 생성 세균의 수는 저장 기간이 길어짐에 따라 감소하였 으며, 그 폭은 삼출액의 종류마다 달랐다. 젖산세균으로서 $L$. homohiochii SS2-22, L. plantarum SS2-29를 분리 및 동정하 였으며, 이들 균주는 고농도의 당에서 생육할 수 있으며, 또한 다량의 젖산을 생산함을 알 수 있었다. 이러한 연구 결과는 당을 이용한 삼출액을 제조하는 식품산업을 과학적으로 발전 시키는 데 도움이 될 수 있을 것으로 사료된다. 

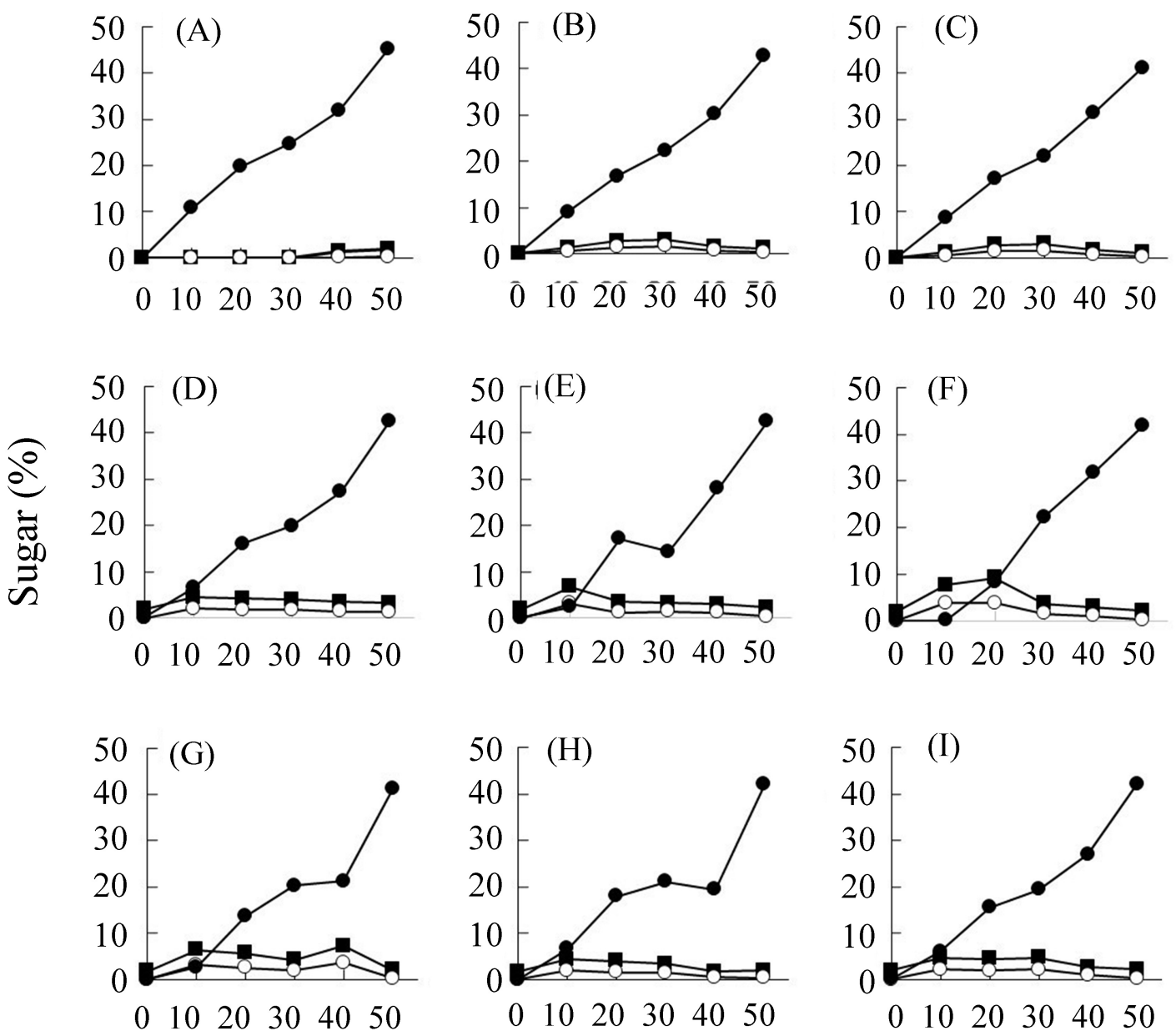

\section{Added sucrose (\%)}

Fig. 6. Changes in sucrose, glucose, and fructose amounts in MRS broth with added sucrose fermented by isolated bacterial strains.

(A)-(I) represent the isolated bacterial strains SS2-22, SS2-29, AS1-10, KJ3-19, KS3-2, KJ6-1, KJ6-2, KJ6-12, and KS6-2, respectively. Sucrose concentrations were $0,10,20,30,40$, and $50 \%(\mathrm{w} / \mathrm{w})$. Filled circle $(\mathbf{O})$, sucrose; filled square $(\mathbf{\square})$, glucose; open circle $(\bigcirc)$, fructose. Fermentation period was 4 days. Data points are mean values \pm SE $(n=3)$.

\section{요 약}

다시마, 양파, 알로에, 매실 그리고 케일의 가식 부분을 대 상으로 하여 설탕을 사용한 당장법으로 삼출액을 제조하고, 이를 제조 1 개월 후부터 1년까지 항아리와 스테인리스강 용 기에 저장하면서 기간별로 당분과 유기산 함량의 변화를 조 사하고, 젖산을 생성하는 우점종 세균을 분리 및 동정하였다. 양파와 알로에 삼출액은 젖산 음료에 해당하며, 다시마의 경 우 젖산과 초산이 함유되어 있었다. 케일 삼출액 중의 주된 유기산은 초산이었고, 매실액은 구연산 함량이 높았다. 또한, 용기가 삼출물의 종류에 따라 그 삼출물의 조성에도 영향을 미치는 것을 확인하였다. 삼출액의 $\mathrm{pH}$ 는 전반적으로 낮아졌
으며, 일반세균수와 젖산 생성 세균수는 저장 기간이 늘어남 에 따라 점점 감소하거나 검출되지 않았다. 세균수는 매실 삼 출액의 경우에만 측정되지 않았으며, 모두 18 종의 우점종 젖 산생성 세균이 확인되었다. $16 \mathrm{~S} \mathrm{rRNA}$ 유전자 염기서열을 확 인한 결과, 이들 미생물은 모두 L. homohiochii, L. plantarum 그리고 B. megaterium 속으로 분류되었다. 이 중에서 염기서 열이 서로 다른 9 종의 미생물을 설탕 첨가 배지에서 4 일 동 안 배양한 결과, $10 \%$ 이하의 조건에서 모두 잘 자랐으며, 특 히 Lactobacillus 속은 내당성이 커서 20-50\%의 높은 당 농 도에서도 생육하였다. 이들은 종에 따라 차이는 있지만, 설탕 을 포도당과 과당으로 가수분해하며, 젖산을 발효 생산하였 다. 우점종 젖산 생성 세균이 삼출액의 종류에 따라 서로 다 

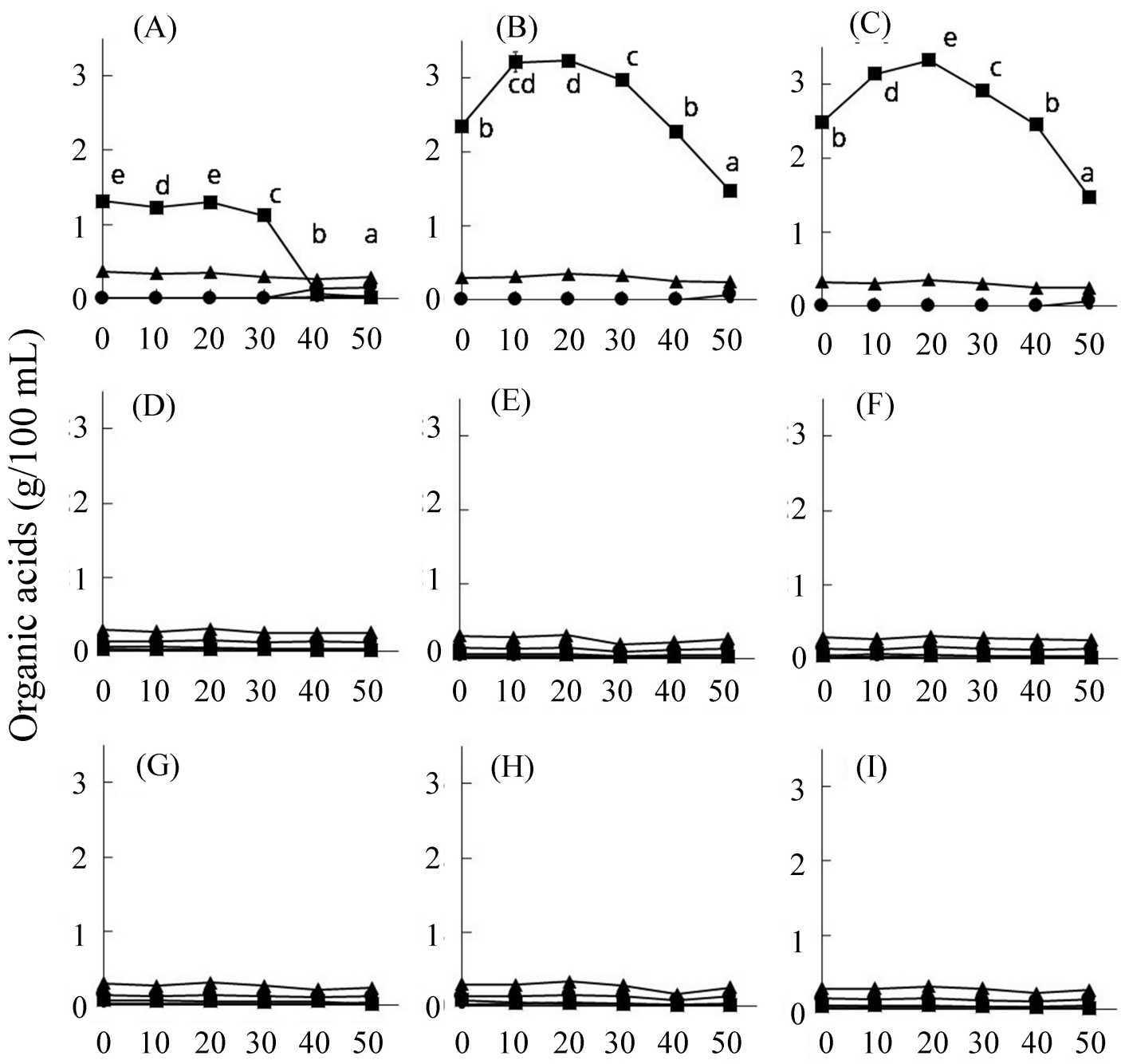

Added sucrose $(\%)$

Fig. 7. Changes in organic acid content in fermented MRS broth with added sucrose by isolated bacterial strains.

(A)-(I) represent the isolated bacterial strains SS2-22, SS2-29, AS1-10, KJ3-19, KS3-2, KJ6-1, KJ6-2, KJ6-12, and KS6-2, respectively. Sucrose concentrations were $0,10,20,30,40$, and $50 \%(\mathrm{w} / \mathrm{w})$. Fermentation period was 4 days. Data points are mean values $\pm \mathrm{SE}(\mathrm{n}=3)$. ${ }^{\mathrm{a}-\mathrm{e}} \mathrm{Values}$ with different superscripts within a panel are significantly different by Duncan's multiple range test at $\mathrm{p}<0.05$.

름도 확인하였다. 이 연구 결과는 이들 미생물을 스타터로 하 여 당장법에 따른 삼출액을 제조하는 등 식품산업에 응용될 수 있을 것이다.

\section{Conflict of interests}

The authors declare no potential conflict of interest.

\section{ORCID}

Mi-Young Choi https://orcid.org/0000-0003-1038-6237
Deok-Young Jhon

https://orcid.org/0000-0001-6864-840X

\section{References}

Ayaz FA, Glew RH, Millson M, Huang HS, Chuang LT, Sanz C, Hayirlioglu-Ayaz S. Nutrient contents of kale (Brassica oleraceae L. var. acephala DC.). Food Chem, 96, 572-579 (2006)

Bae HN, Kim YM. Improvement of the functional qualities of sea tangle extract through fermentation by Aspergillus 
oryzae. Fish Aqua Sci, 13, 12-17 (2010)

Bae JH, Kim KJ, Kim SM, Lee WJ, Lee SJ. Development of the functional beverage containing the Prunus mume extracts. Korean J Food Sci Technol, 32, 713-719 (2000)

Baker GC, Smith Jj Fau-Cowan DA, Cowan DA. Review and re-analysis of domain-specific 16s primers. J Microbiol Methods, 55, 541-555 (2003)

Bracco U, Loeliger J, Viret JL. Production and use of natural antioxidants. J Am Oil Chem Soc, 58, 686-690 (1981)

Cheigh HS, Kim HY, Yeo KM, Kim BN. Fermentation aspects of fruit-vegetable juice by mixed cultures of lactic acid bacteria isolated from kimchi and yeast. J Korean Soc Food Sci Nutr, 27, 1059-1064 (1998)

Cho YJ, An BJ, Kim MU, Shim CS. Anti-inflammatory effect of Aloe vera and Aloe arborescens in phosphatidic acid-stimulated raw cells. J Korean Soc Appl Biol Chem, 49, 65-69 (2006)

Chuda Y, Ono H, Ohnishi-Kameyama M, Matsumoto K, Nagata T, Kikuchi Y. Mumefural, citric acid derivative improving blood fluidity from fruit-juice concentrate of japanese apricot (Prunus mume Sieb. Et Zucc). J Agric Food Chem, 47, 828-831 (1999)

El-Demerdash FM, Yousef MI, El-Naga NIA. Biochemical study on the hypoglycemic effects of onion and garlic in alloxan-induced diabetic rats. Food Chem Toxicol, 43, 57-63 (2005)

Ha MH, Park WP, Lee SC, Choi SG, Cho SH. Antimicrobial characteristic of Prunus mune extract. Korean J Food Preserv, 13, 198-203 (2006)

Han KI, Kim MJ, Kwon HJ, Kim YH, Kim WJ, Han MD. The effect of container types on the growth of bacteria during kimchi fermentation. Korean J Food Nutr, 26, 249-257 (2013)

Han SY, Yeo SH, Jeong ST, Choi HS, Baek SY, Park HY. Status and prospect of plant fermented liquid in Korea. Food Sci Ind, 45, 31-43 (2012)

Hertog MGL, Hollman PCH, Katan MB. Content of potentially anticarcinogenic flavonoids of 28 vegetables and 9 fruits commonly consumed in the Netherlands. J Agric Food Chem, 40, 2379-2383 (1992)

Hwang JY, Ham JW, Nam SH. The antioxidant activity of maesil (Prunus mume). Korean J Food Sci Technol, 36, 461-464 (2004)
Jeong $\mathrm{CH}$, Heo HJ, Choi SG, Shim KH. Antioxidant and anticancer properties of methanolic extracts from different parts of white, yellow, and red onion. Food Sci Biotecnol, 18, 108-112 (2009)

Kim HJ, Chun HS. Biological functions of organosulfur compounds in Allium vegetables. J Korean Soc Food Sci Nutr, 28, 1412-1423 (1999)

Kim JH, Cho HD, Won YS, Park WL, Lee KW, Kim HJ, Kwon-Il S. Physiological activity and physicochemical properties of condensed Prunus mume juice prepared with pectinase. J Life Sci, 28, 1369-1378 (2018)

Kim MG, Oh MS, Kang SH, Kim HT, Yoon MH. A study on contents of sugar and the activities of amylase in enzyme foods and enzyme-shaped foods. J Food Hyg Saf, 30, 359-365 (2015)

Kim MJ, Yang SA, Park JH, Kim HI, Lee SP. Quality characteristics and anti-proliferative effects of dropwort extracts fermented with fructooligosaccarides on HepG2 cells. Korean J Food Sci Technol, 43, $432-437$ (2011)

Kim MR, Kim JH, Wi DS, Na JH, Sok DE. Volatile sulfur compounds, proximate components, minerals, vitamin $\mathrm{C}$ content and sensory characteristics of the juices of kale and broccoli leaves. J Korean Soc Food Sci Nutr, 28, 1201-1207 (1999)

Kim SG, Bang KW, Woo SO, Kim SK, Kim HY, Choi HM, Moon HJ, Han SM. Citric acid, minerals contents, and antioxidant activities of maesil (Prunus mume fruit) cheongs formulated using different honeys. J Apic, 35, 75-80 (2020)

Kim YW, Im HE, Jeong ST, Yeo SH, Baek SY, Park HY. Quality status of commercial fermented liquid in Korea. Food Ind Nutr, 18, 23-32 (2013)

Ko MS, Yang JB. Antimicrobial activities of extracts of Prunus mume by sugar. Korean J Food Preserv, 16, 759764 (2009)

Kwak HJ, Kwon YJ, Jeong PH, Kwon JH, Kim HK. Physiological activity and antioxidative effect of methanol extract from onion (Allium cepa L.). J Korean Soc Food Sci Nutr, 29, 349-355 (2000)

Kwon YJ, Kwon JH, Kim HK. Oleoresin content and functional properties of fresh onion by microwave: Assisted extraction. J Korean Soc Food Sci Nutr, 28, 876-881 (1999)

Lee EJ, Lee CH. Effective components of commercial enzyme 
food products and their HACCP scheme. Korean J Food Sci Technol, 33, 461-468 (2001)

Muñoz O, Leal X, Quitral V, Cardemil L. Extraction, characterization and properties of the gel of Aloe vera (Aloe barbadensis Miller) cultivated in chile. Med Aromat Plants, 4, 1-7 (2015)

Noisopa C, Prapagdee B, Navanugraha C, Hutacharoen R. Effects of bio-extracts on the growth of Chinese kale. Kasetsart J Nat Sci, 44, 808-815 (2010)

Oancea S, Draghici O. $\mathrm{pH}$ and thermal stability of anthocyanin-based optimised extracts of romanian red onion cultivars. Czech J Food Sci, 31, 283-291 (2018)

Okai Y, Higashi-Okai K, Nakamura SI. Identification of heterogenous antimutagenic activities in the extract of edible brown seaweeds, Laminaria japonica (Makonbu) and Undaria pinnatifida (Wakame) by the umu gene expression system in Salmonella typhimurium (ta1535/ psk1002). Mutat Res Lett, 303, 63-70 (1993)

Park GY, Jang HW, Kim KM, Hwang Y, Kim HY, Cho YS. Changes on the quality characteristics of Prunus davidiana sugar extracts by processing conditions. Food Eng Prog, 24, 214-220 (2020)

Park HS, Kim DS, Kim HS, Lee YG, Chung HS. Effect of freezing pretreatment on the quality of osmotically extracted syrup from Citrus junos peel. Korean J Food Preserv, 27, 1-6 (2020)

Park KY, Lee KI, Rhee SH. Inhibitory effect of green-yellow vegetables on the mutagenicity in salmonella assay system and on the growth of az-521 human gastric cancer cells. J Korean Soc Food Sci Nutr, 21, 149-153 (1992)

Park MW, Kim MR, Lim KT, Park ST, Shim JH. Screening of antioxidant in fructus mune (Prunus mune Sieb. Et Zucc.) extract. J Korean Soc Agric Chem Biotechnol, 45, 119-123 (2002)

Park PJ, Kim EK, Lee SJ, Park SY, Kang DS, Jung BM, Kim KS, Je JY, Ahn CB. Protective effects against $\mathrm{H}_{2} \mathrm{O}_{2}$-induced damage by enzymatic hydrolysates of an edible brown seaweed, sea tangle (Laminaria japonica). J Med Food, 12, 159-166 (2009)

Rice KC, Bayles KW. Molecular control of bacterial death and lysis. Microbiol Mol Biol Rev, 72, 85-109 (2008)

Saitou N, Nei M. The neighbor-joining method: A new method for reconstructing phylogenetic trees. Mol Biol Evol, 4, 406-425 (1987)

Shin SC. Changes in components of ume fruit during development and maturation. Korean J Plant Res, 8, 259-264 (1995)

Son MJ, Cha CG, Park JH, Kim CS, Lee SP. Manufacture of dropwort extract using brown sugar, fructose syrup and oligosaccharides. J Korean Soc Food Sci Nutr, 34, 1485-1489 (2005)

Song HN, Jung KS. Quality characteristics and physiological activities of fermented soybean by lactic acid bacteria. Korean J Food Sci Technol, 38, 475-482 (2006)

Tamura K, Dudley J, Nei M, Kumar S. Mega4: Molecular evolutionary genetics analysis (mega) software version 4.0. Mol Biol Evol, 24, 1596-1599 (2007)

Wang Y, Tang XX, Yang Z, Yu ZM. Effect of alginic acid decomposing bacterium on the growth of Laminaria japonica (Phaeophyceae). J Environ Sci, 18, 543-551 (2006)

Warnecke T, Gill RT. Organic acid toxicity, tolerance, and production in Escherichia coli biorefining applications. Microb Cell Fact, 4, 25 (2005)

Xia D, Shi J, Gong J, Wu X, Yang Q, Zhang Y. Antioxidant activity of Chinese mei (Prunus mume) and its active phytochemicals. J Med Plant Res, 4, 1156-1160 (2010)

Yang YR, Kim HL, Park YK. Effects of onion kimchi extract supplementation on blood glucose and serum lipid contents in streptozotocin-induced diabetic rats. J Korean Soc Food Sci Nutr, 37, 445-451 (2008)

Yoo HJ, Lee SH, Lee DS, Kim HB. Antioxidant activity of fermented barley, wormwood, sea tangle, and soybean. Korean J Microbiol, 38, 230-233 (2002) 